\title{
科罗拉多州的珍贵财富: 美国25号州际公路廊道保护总体规划 A COLORADO LEGACY: INTERSTATE 25 CONSERVATION CORRIDOR MASTER PLAN
}

\section{1 项目背景}

美国25号州际公路（I-25）在科罗拉多一怀俄明两州交界处向南 部延伸至科罗拉多斯普林斯一段，走向与科罗拉多州的弗兰特山脉平 行。这条长约104.6km的廊道沿途景观从起伏的草原渐渐过渡至派克峰 区，有着世界上最壮美的景致，包括久负盛名的眺望景观、生机勃勃 的畜牧场、各种野生动物的栖息地、具有重要价值的生态系统，以及 人们珍视的休闲生活。

20世纪下半叶, 由于优美的景色和毗邻大都市的优越地理位置, I-25廊道被列为主要开发对象, 当地居民和游客因此而无法再欣赏到 这条连绵而壮阔的天际线。作为连接丹佛和科罗拉多斯普林斯这两个 科罗拉多州最大的城市的纽带，I-25廊道为道格拉斯郡南部约 300 万人 提供了生活、工作和娱乐空间; 而这里也是自 20 世纪 80 年代早期起, 全美发展最迅速的郡县之一：仅1990 1995年间, 城市增长率㕮升至 $45.8 \%$, 大量的土地被用于以道路为主的开发建设

随着大规模建设的开展，人们想要保护科罗拉多州土地和风景资 源的愿望越来越迫切。但由于快速的建设扩张、公共土地征用成本高 昂、鼓励基础设施大举建设的政策的推行，加之科罗拉多州法律中未
理查德・肖

盖国景观设计师协会荣誉会员, Design Workshop设计事务所首 席设计师

摘要

美国25号州际公路在科罗拉多 - 怀俄明两州 交界处向南延伸至科罗拉多斯普林斯一段，走向 与科罗拉多州的弗兰特山脉平行一一那里拥有世 界上最壮美的景致。但同时, 这里也曾是美国一 处发展讯猛的地区，开发建设不断改变着当地的 天际线，影响着风景品质。科罗拉多州自然保护 信托基金会与Design Workshop设计事务所展开 合作, 启动了25号州际公路廊道保护总体规划项 目，鼓励各个保护组织、政府机构、私人土地所 有者和当地居民参与到公共开放土地的保护工作 中, 以实现对眺望景观、水质、野生动物、空气 及休闲空间的永久保护。该规划旨在为当地无节 制的扩张建设提供解决方案, 利用独特的规划方 法和适度开发策略，来实现曾经被认为是遥不可 及的目标: 保护科罗拉多州弗兰特山脉周边超过 $405 \mathrm{~km}^{2}$ 的开放空间。

关键词

保护; 规划; 管理; 政治协调; 科罗拉多州; 增 长管理

\section{Richard SHAW*}

Fellow of American Society of Landscape Architects; Principal at Design Workshop, Inc

*Corresponding Author

* Corresponding Author Emaits.

\section{ABSTRACT}

Colorado's Front Range runs parallel to Interstate 25 from the Wyoming border to the Colorado Springs, offering some of the most spectacular scenery in the world. This area of the United States was growing fast and development and construction continued to change the skyline. Colorado Conservation Trust Fund, in collaboration with Design Workshop Inc., initiated the Interstate 25 Conservation Corridor Master Plan to engage conservation organizations, government entities, private landowners, and residents in conserving open lands to forever protect scenic vistas,

water quality, wildlife, clean air, and recreational opportunities along the corridor. Devised to offer solutions to the surrounding uncontrolled sprawl, the plan leveraged unique planning methods and limited development strategies to achieve what had been previously considered impossible: the preservation of over 100,000 acres of open space along Colorado's Front Range.

\section{KEY WORDS}

Conservation; Planning; Stewardship; Political Coordination; Colorado; Growth Management
编辑、翻译 田乐

EDITED AND TRANSLATED BY Tina TIAN 
1. $1-25$ 廊道连接着丹佛和 科罗拉多斯普林斯这两 个科罗拉多州最大的城 个科罗拉多州最大的城 了生活、工作和加乐空 间。但这里正被无节制 的发展和肆意的郊区扩 张所占据。

廊道保护规划愿景：总 体规划旨在保护该区域 内具有独特环境价值的 片区。该项目采用了一 种有别于传统坝划实践 种有别于传统规划买践 的方式, 为约 $130 \mathrm{~km}^{2}$ 土地制定了保护方 案, 并针对公共土地流 失问题提出了新型解决 方案。

I-25 connects

Colorado's two largest cities, Denver and

Colorado Springs. This corridor is accessible

to 3 million people who live, work, and play here. Uncontrolled growth and endless suburban sprawl loomed as the probable outcome

Vision of

conservation corridor plan: The master plan was developed to preserve environmentally unique places at a regional scale. This plan introduced planning practices, resulting in the preservation of 32,000 acres of land and an alternative solution to the loss of open lands.

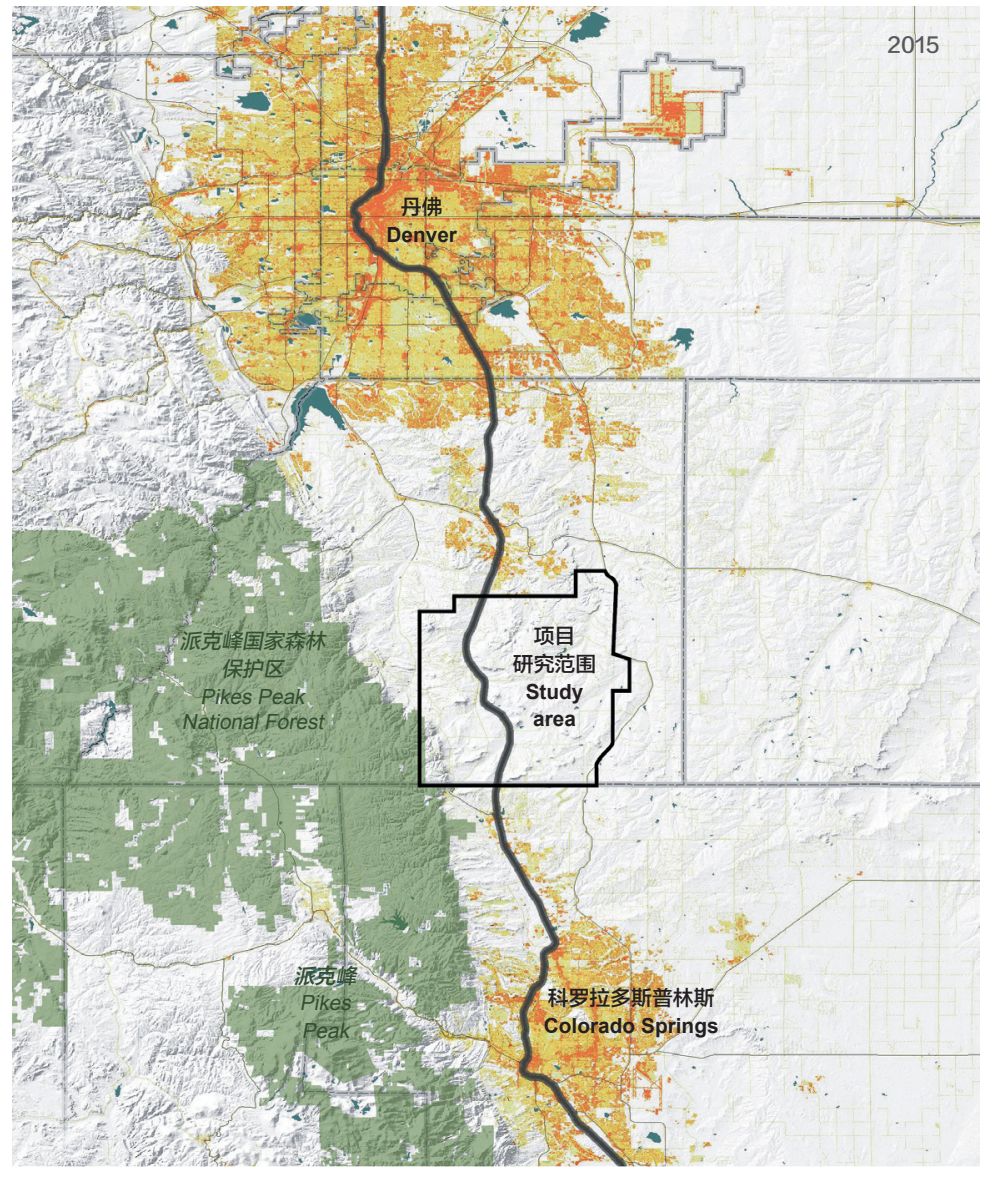

- 高强度开发区 High intensity development

= 城郊开发区 Suburban development

，低强度开发区 Low intensity development

I1 $\quad$\begin{tabular}{llrr}
0 & $5 \quad 10 \quad 20 \mathrm{~km}$ \\
\hline
\end{tabular}

对 $14 \mathrm{hm}^{2}$ 以下面积的地块的建设用途加以限定（这意味着土地所有者有 可能不遵循传统土地规划模式来对土地加以利用），导致保护的难度 日益加大。

为了应对 I- 25 廊道沿线地区无序发展这一紧迫问题，Design Workshop设计事务所接受委托，负责制定和实施 $\mathrm{I}-25$ 廊道保护总体规 划, 希望通过与保护组织、政府部门和私人土地所有者进行前所未有 的合作, 永久保护这条廊道中的眺望景观、水质、野生动物、空气和 休闲空间。该规划还计划运用多种技术手段和适度开发策略, 来实现 曾经被认为是遥不可及的目标：保护科罗拉多州弗兰特山脉周边广阔 的开放空间。

\section{2 自然条件}

一个场地的自然价值是由一系列物理因素相互作用而决定的，包

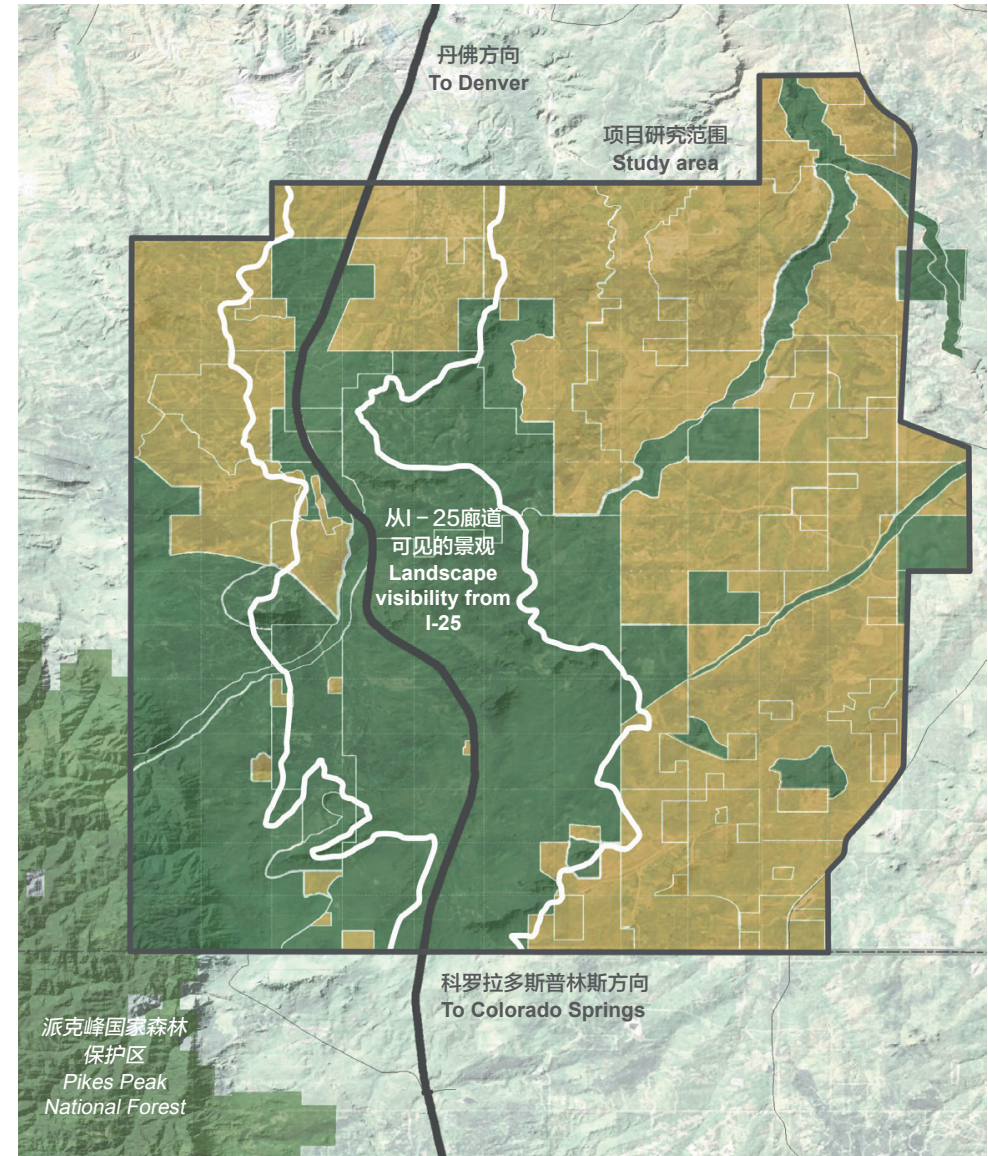

$\Rightarrow$ 保护区 Conserved lands

= 适度开发区 Limited development

11 $0 \quad 125 \mathrm{~km}$
括气候、地质、水文和植被条件。科罗拉多弗兰特山脉地区属半干旱 气候，环境怡人。然而，项目规划区域受到当地孤峰和山脊局地地形 和植被的强烈影响，时常会形成剧烈风廊。区域南部是普拉特河和阿 肯色河的分水岭，以极端气候条件而闻名。

水无疑是弗兰特山脉面临的一个关键问题，因为当地的既有开 发严重依赖非可再生性地下水源，特别是丹佛流域的 4 个含水层。尽 管专家们对这种水资源供给所能持续的时间看法不一, 但他们都一致 认为, 未来的非可再生性水资源将愈发短缺。规划区域位于这些含水 层系统之上，专家认为这里将成为该区域未来宝贵的水源。项目区域 内的地表水包括樱桃河、西梅河、卡朋特河等重要河流及其支流; 还 有若干季节性河流及许许多多的牲畜饮水塘; 与这些河道相邻的河滨 带, 以及其他沼泽和湿地都是极具生态价值的区域; 主要河流周边都 伴有面积可观的冲积漫滩。

该区域存在三种重要的生态系统：草地、针叶林和灌从。占项 


3. 区域发展的历史肌理与增 长预测: 为了应对 $1-25$ 廊道沿线地区无序发展这 一紧迫问题, 环境组织。 土地信托基金会、当地社 区 道格垃斯郡政府及科 一个非常圲联明，以制定 弗兰特
件 保护从东部大草原延伸至 弗兰特山脉的连绵的山地 眺望景观, 丰富公共休 闲生活是总体规划的基本
5. 增长和发展压力: 尽管制 定了发展原景和保护计 划, 但由于道格拉斯郡法 规对开发选址和项目类型 尚无明确规定, 导致规划 在实施之初受挫。此外, 科罗拉多州法律中未对

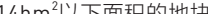 建设用途加以限定。

3. Historic pattern of
development and
forecasted growth:
Prompted into action by
record and uncontrolled
growth along the -25
Corridor, environmental
groups, land trusts,
local communities,
Douglas County, and
state agencies formed
an unusual coalition
to create a regional
conservation vision for
the Front Range.
Mountain, prairies, and
outdoor recreation: The
vision of continuous
scenic vistas from the
eastern prairies to the
mountainous landscape
of the Front Range,
combined with abundant
public recreation, is the

fundamental objective of the master plan. Growth and development pressures: Despite being armed with a vision and a plan for preservation, success was initially curtailed due to lack of county regulations directing location an type of development. Also, state laws exempted parcels of 35 acres from subdivision standards. 
目场地面积一半以上的草地生态系统曾一度以格兰马草 (Bouteloua gracilis ) 为优势物种, 但外来物种的人侵和数十年的过度放牧改变了草 地生态系统的面貌; 以西黄松 (Pinus ponderosa) 为主的针叶林分布于 区域中较为干燥、阳光充足的地带, 但不幸的是, 这些林地已经受到 了人工景观种植和住宅开发的严重影响; 灌丛生态系统主要分布于草 地和针叶林群落之间, 以矮栋为主, 构成了可适应未来气候变化的理 想韧性景观。

科罗拉多野生动物保护司对规划区域进行了详细研究, 发现当 地野生动物活动迹象有所增多。例如, 在格陵兰牧场发现了䴪鹿群 居和迁徙的踪迹；在拉克斯本山上的岩石峭壁上观察到了大角羊； 加之已知栖居在此的尖尾草原松鸡, 尽管它们的种群数量可能正在减 少; 此外, 还发现了美洲狮、黑熊、金雕、火鸡和成群的鹿和羚羊出 没于此。

这些自然价值共同决定了场地保护策略方向, 因为项目区域不仅 拥有重要的生态系统和栖息中心, 同时也是数个已知的重要生态区域 的关键性连接点。

\section{3 保护策略}

项目研究区域面积超过 $405 \mathrm{~km}^{2}$, 由北至南长约 $24 \mathrm{~km}$ 。该规划需要 进行大量研究以确定关键地块、指导实施工作并确定资金来源。规划 团队收集了自然资源价值的既有信息; 确定了那些尚未辨识关键栖息 地的额外资源清单; 借助测绘来判断重要的视觉廊道和风景资源; 对 特定的物业财产进行了初步评估; 对土地保护策略的实施提出具体建 议, 包括收费、保护地役权抵押、租赁和管理协议等事宜; 分析了适 度开发方案; 与土地所有者洽谈; 调查和评估包括私人投资者和保护 地块买家在内的潜在公共和私人资金来源。

规划团队决定对那些植被情况复杂、野生动物数量较多, 或者拥 有重要景观的地块进行优先保护。数据收集和地图绘制工作历时数 月, 涵盖景观廊道、地形、土地覆盖、自然灾害、土地价值、分区、 土地所有权、景致特征、野生动植物栖息地和迁徙、地下水可用 程度、休闲活动的趋势、历史遗迹, 以及既有开发项目的投资情况等 方面。

在指定区域进行的适度开发将有助于为开放空间筹募更多的资 金、促进未来增长和经济发展, 并为科罗拉多州及美国西部其他地区 提供可借鉴的保护模式。

该地区具有重要的休闲和公共利用价值。因而规划还将确保当地 居民和游客可以体验丰富多样的活动, 包括远足和骑行等传统休闲活 动, 以及野生动物观察和环境教育等项目。

根据项目区域的自然价值, 规划确定了三个保护层级。最关键的 保护区 (或野生动物高敏感区) 面积约为 $18.2 \mathrm{~km}^{2}$, 这些区域应保持 其现有状态或对自然及野生动物栖息地稍加管理, 并严格限制人为使 用; 其余区域则可适度开展人类活动。
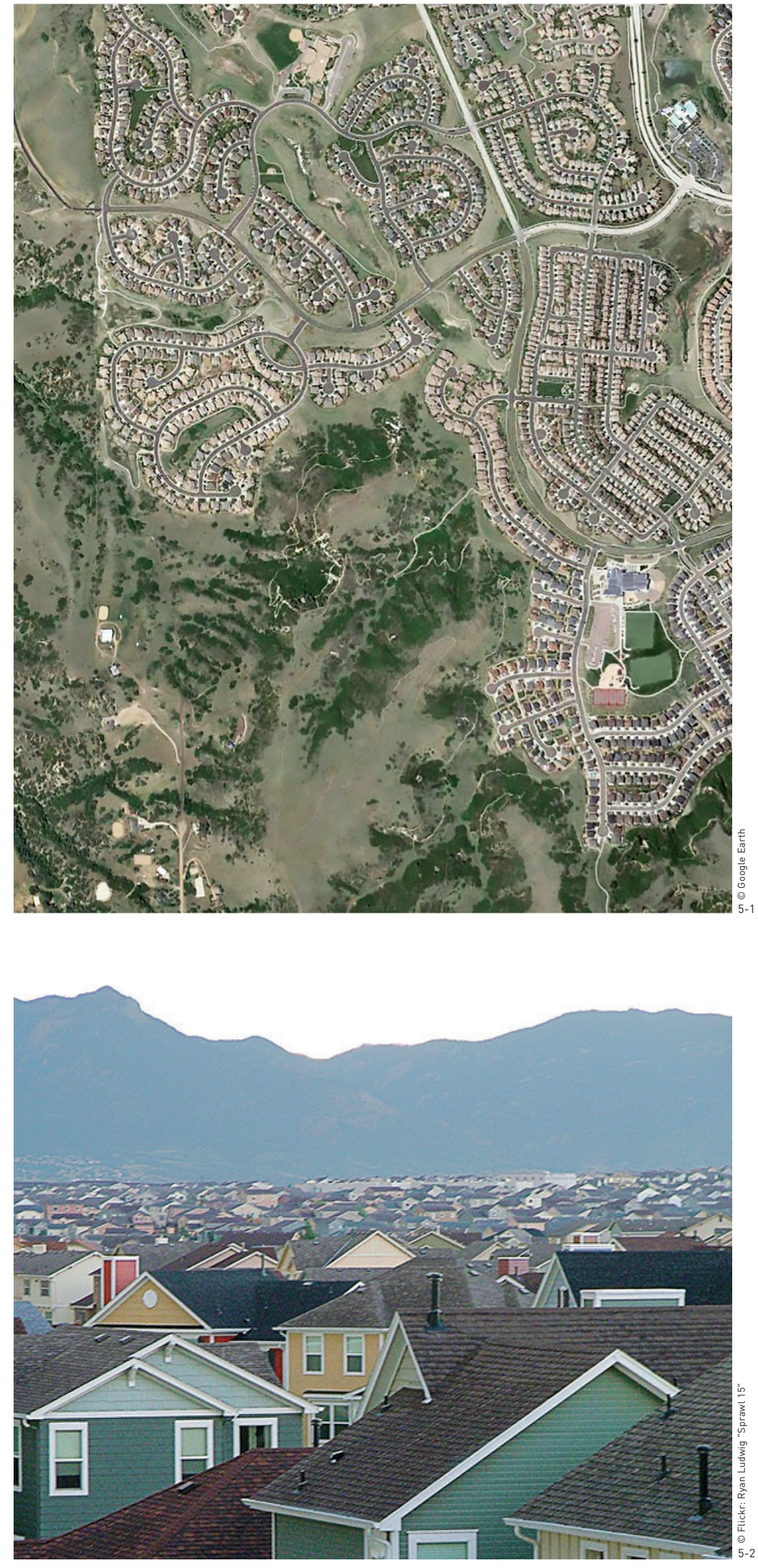


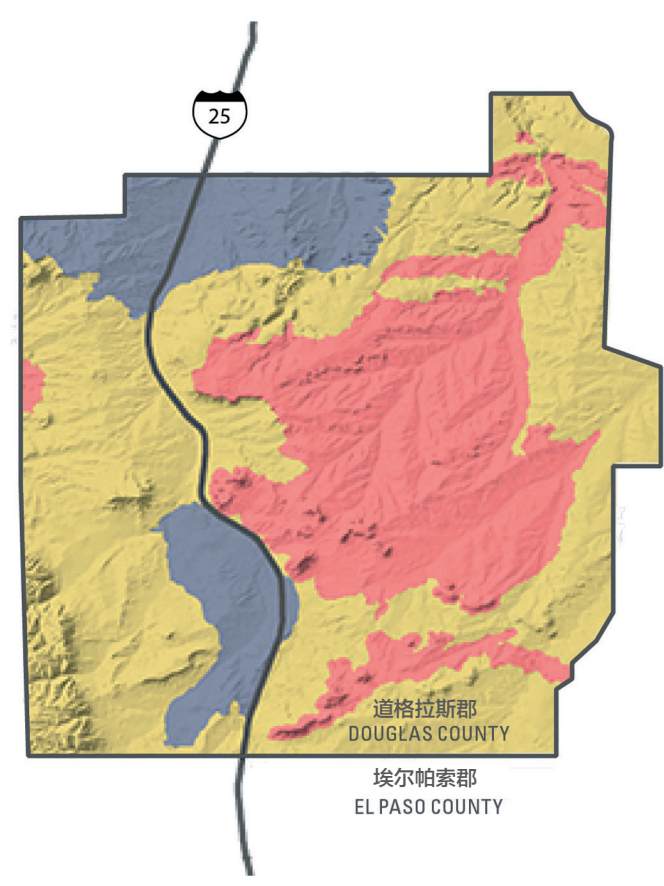

开发对野生动物的影响程度 Wildlife sensitivity to change

高 High

中 Medium

低 Low
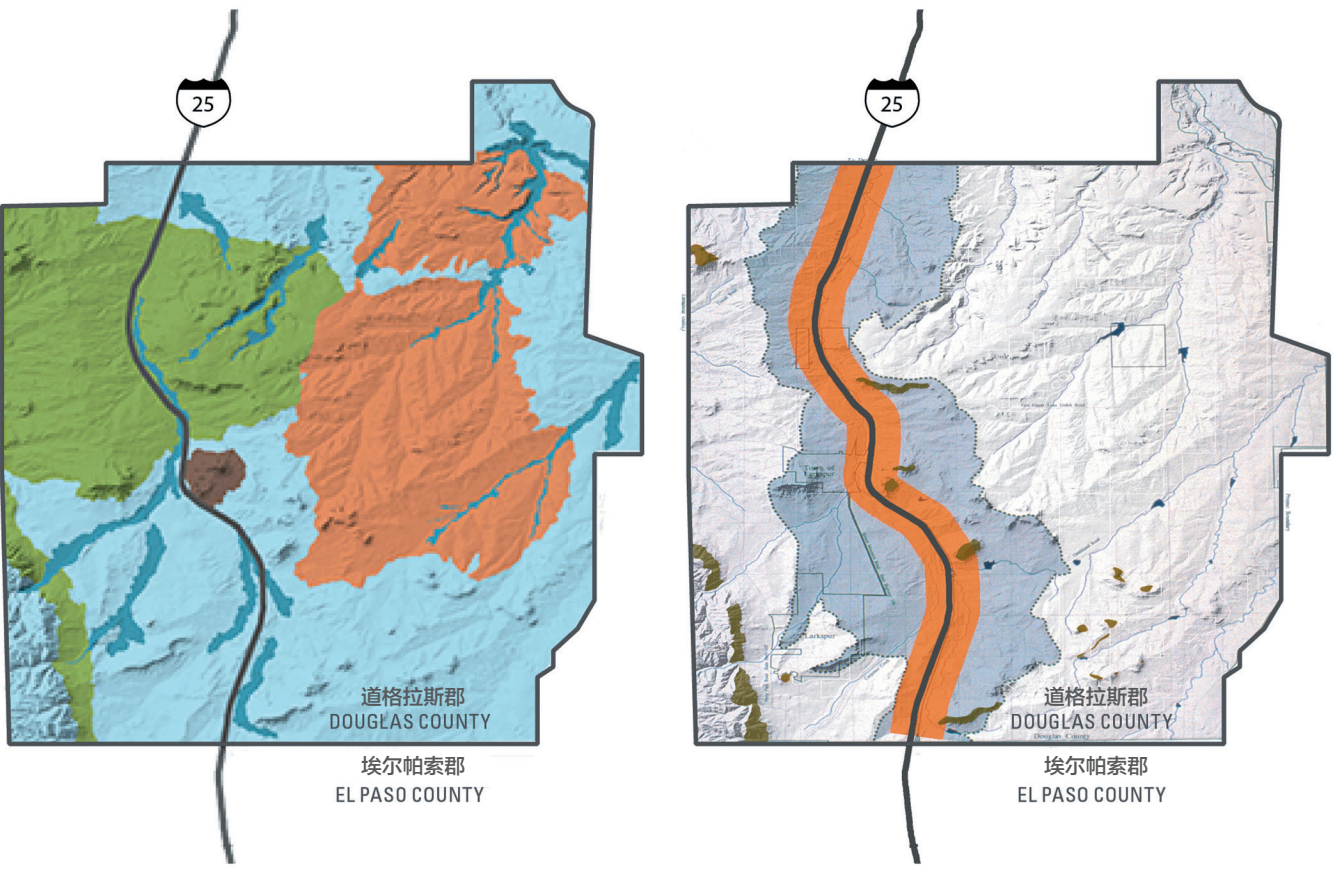

视觉偏好与价值

Visual preference and value

滨水廊道

Riparian corridor

迁徙廊道/重要山脊

Migration corridor / critical rang

生物多样性强

High biodiversity

已确定的濒危物种栖息地

dentified endangered species habita

生物多样性次级保护区

Secondary areas of biodiversity
6. 自然资源价值评估：公 民调查表明，当地居民 非常希望能够拥有开 放空间。预测性的建 模方法作为一种重要 的分析手段, 可用于确 定最可能存在土地利用 冲突和最应当优先保护 的片区。

7. 确定保护优先级: 在未 来发展规划方面, 项目 首先明确了保护和自然 首先源价保了然后扣自然 响乡村特色或公共土地 响乡村特色或公共土地 价值的前提下进行建筑 选址。

6. Assessing natural resource values: Citizen surveys indicate that open space is highly open space is highty desired by regional residents. Predictive modeling methods were important analytical tools used to determine where land use conflicts were most likely to exist and which lands were priorities for conservation.

\section{高价值的自然环境 \\ High value natural systems}

视觉特征/地标景观 Visual feature / landmark landscape

开阔的前景视野

Open foreground view

具有重要视觉价值的中景地区

Middle ground with high visual valuation

conservation.

conservation priority: It is possible to plan for future development by defining conservation and natural resource values first and then establishing location for building sites which will not affect rurat will not affect rural character or the values of open lands.

\section{4 利益相关者、优先层级与利益冲突}

项目的关键目标之一是鼓励广泛的公共、私营合作伙伴参与到规 划过程当中，并通过系列研讨会和工作坊的形式，来增进与项目相关 或对项目感兴趣的各方群体对规划方案的了解，并进行意见收集。利 益相关者包括：

1 ) 州政府: 科罗拉多州州长办公室和科罗拉多州交通部;

2 ) 郡政府：道格拉斯郡议事委员会、道格拉斯郡开放空间指导委 员会和道格拉斯郡规划部;

3 ) 市政府: 拉克斯本市政府;

4 ) 企业: Mission Viejo公司 (开发商) 和Hunsperger \& Weston地产 开发有限公司 (房地产评估);

5 ) 准政府组织和非营利组织: 科罗拉多州优秀户外项目信托基金
会、科罗拉多州自然保护信托基金会、盖茨基金会（现为盖茨家庭基 金会）、科罗拉多公共土地管理局和科罗拉多自然遗产计划小组;

6 ）居民和土地所有者。

利益相关者的反馈非常热烈。其中, 当地居民高度重视对开放空 间的保护, 特别是那些拥有重要野生动物栖息地和关键溪流廊道的地 区。与会的所有利益相关方一致表达了希望该规划能够促进道格拉斯 郡的经济增长的迫切需求。

项目运用了城市增长分析模型来预测 I- 25 廊道沿线地区适合在第 一批进行开发的地块位置。项目区域内的土地所有权边界非常独特, 其中某些大面积地块归单一产权人所有。项目地块的面积从几平方公 里到近百平方公里不等。最适宜的开发方式包括：

1 ) 将开发集中在低敏感区域，以保护那些珍贵的开放空间。例 如, 如果一块住宅建设用地的面积为 $14 \mathrm{hm}^{2}$, 那么可以在原本用于建设 

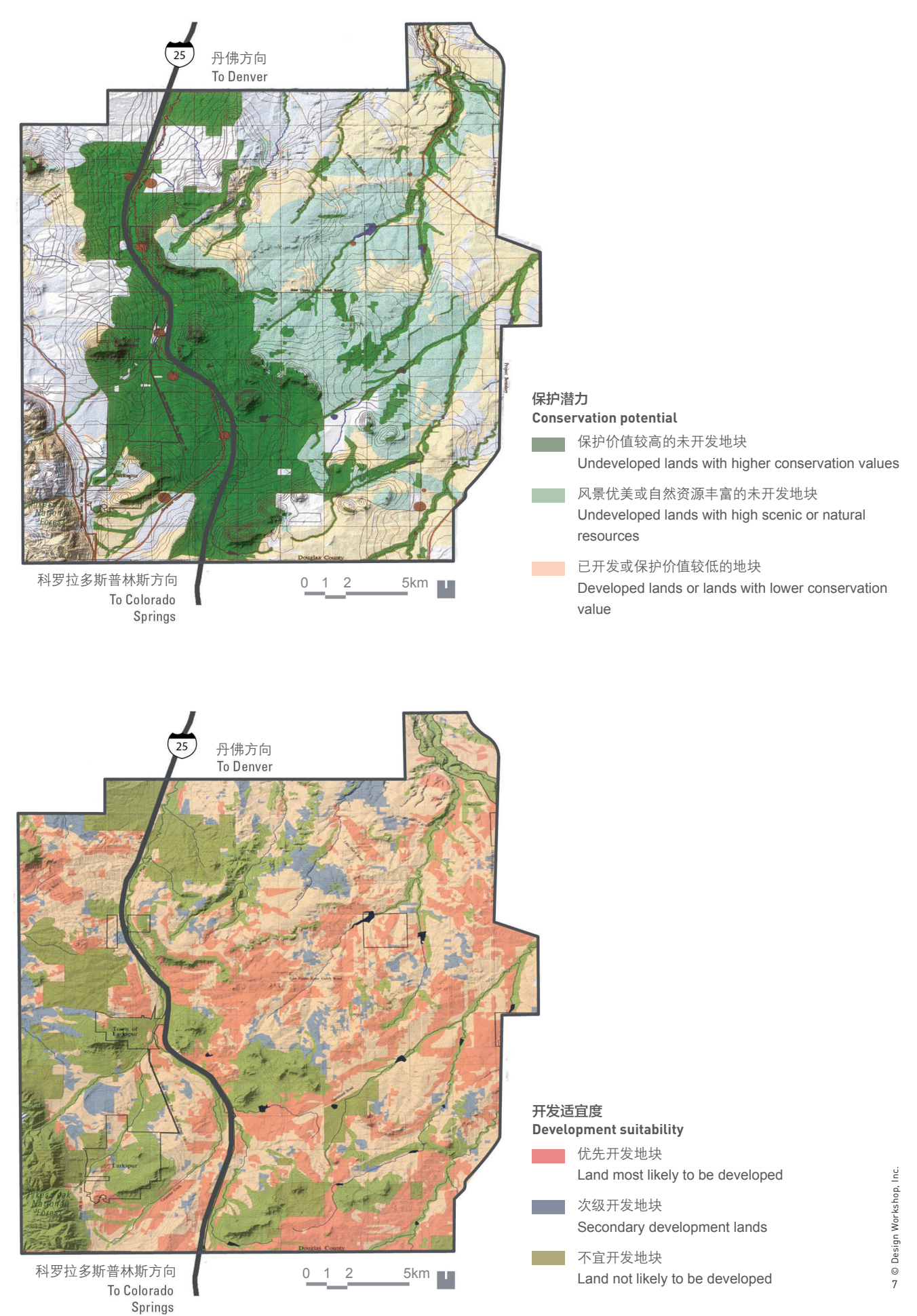

三处住宅的土地上仅用 $6 \mathrm{hm}^{2}$ 集中建设住宅，留下 $36 \mathrm{hm}^{2}$ 的保护地块。道 格拉斯郡鼓励这种开发模式。

2 ）通过适度开发，减少既有开发区划中的新增建筑物数量，并对 除建筑物以外的区域进行保护地役权抵押。

3 ) 将最小地块割划面积由之前的 $14 \mathrm{hm}^{2}$ 改为 $65 \mathrm{hm}^{2}$ 。道格拉斯郡政 府当时考虑了这一建议，但仍需要州立法的支持。

规划团队基于历史模式创建了一个预测模型，将这些开发地块选 址与自然资源最为丰富、景色最为优美的场地结合起来分析, 以判断 其中可能存在的冲突并确定保护优先级。最终, 将适度开发地点选在 了对土地影响最小、不破坏栖息地或损害景观视线的地方, 这样既可 兼顾资源保护与土地开发，而且还会增加土地的价值。

\section{5 具体建议与实施}

尽管制定了发展愿景，也赢得了公众支持、明确了未来保护的实 施步骤，但由于道格拉斯郡对开发的选址、项目类型及实施进度尚无 明确规定, 导致规划实施受挫。为了推动项目的实施，规划团队与各 个保护组织, 私人土地所有者, 以及州、郡县和地方政府展开通力合 作，筹集资金以保证对重点地块立即开展保护工作。

1996年，科罗拉多州自然保护信托基金会带来的数百万美元的遗 产倡议拨款为项目实施带来了转机，这笔资金被立即用于对重点地块 的保护工作。其余的筹款也用于支付密集开发区划的置地费用。规划 团队还提议, 未来I-25廊道中所有的土地开发计划都应以不损害公共 视野为前提，通过采取集中开发模式、将其余土地进行永久性保护地 役权抵押、为未来业主提供税务优惠等措施，实现开放空间和景观的 永久保护。

规划团队不仅对潜在开发地块的方位、视野、植被、与道路的间 距、工程可行性和朝向等方面提出了具体建议, 还进一步剔除了那些 位于冲积漫滩、陡坡和地质灾害带的地块。此外，已被细分或开发的 （面积不足 $1 \mathrm{hm}^{2}$ 的）地块也被排除在潜在开发地块范围之外。

募集到的资金被用在了能发挥关键作用的地方，这为决策制定、 建立共识和各方协商奠定了基础。该规划还鼓励开发商在具体项目的 详细规划中考虑除经济回报外的景观和自然资源价值, 并帮助自然资 源保护主义者认识到，适度的开发其实是有利于土地保护的。

随着规划团队从愿景规划过渡到实施阶段，复杂的土地交易问题 开始浮现，而设计师在其中发挥了关键作用。例如，在一个重大的实 施环节中, 一个面积为 $526 \mathrm{hm}^{2}$ 的地块上已经开始了道路项目和 40 户住 宅项目的建设，设计团队在科罗拉多州自然保护信托基金会的帮助下 与开发商进行了长达 11 个小时的协调工作。这个地块为公众提供了整 个廊道中观赏派克峰的最佳视野, 景观设计师用在餐巾上画的草图向 开发商展示了环境敏感型集中住宅区的设计理念, 成功说服开发商将 所有的住宅区从公众视野中迁出。

在接下来的几十年间，发展本身成为土地保护的重要途径。时间 


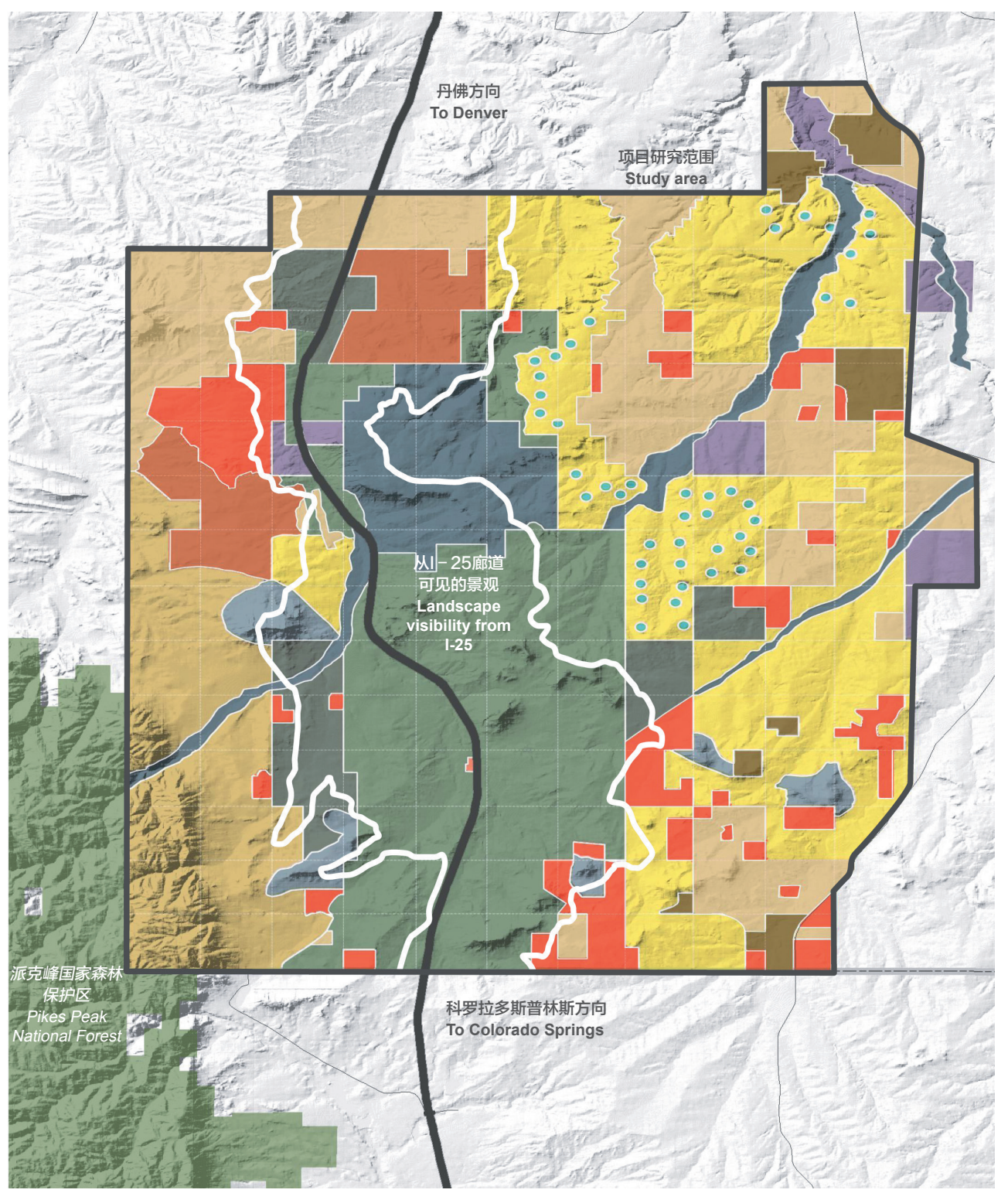

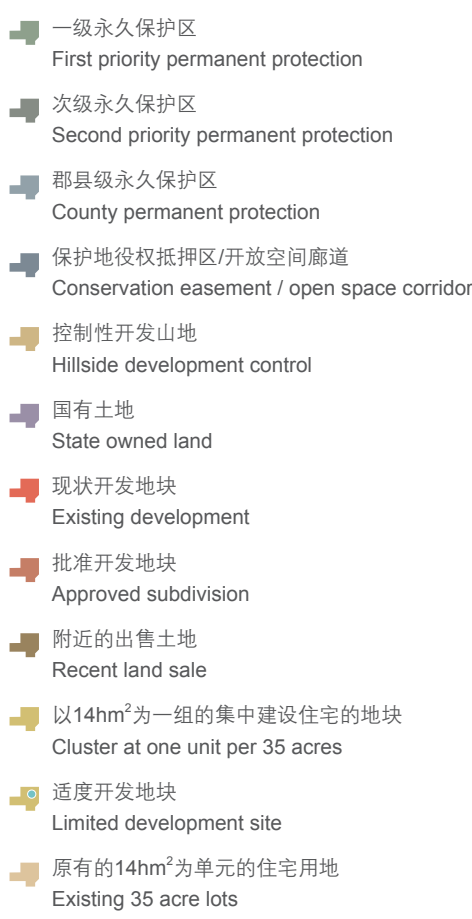

一级永久保护区 First priority permanent protection

次级永久保护区 Second priority permanent protection

郡县级永久保护区

保护地役权抵押区/开放空间廊道

Conservation easement / open space corrido

控制性开发山地

Hillside development control

工国有土地

State owned land

一现状开发地块

Existing development

- 批准开发地块 Approved subdivision

附近的出售土地 Recent land sale

-1. 以 $14 \mathrm{hm}^{2}$ 为一组的集中建设住宅的地块 Cluster at one unit per 35 acres

适度开发地块

Limited development site

原有的 $14 \mathrm{hm}^{2}$ 为单元的住宅用地 Existing 35 acre lots

8. 保护方法: 项目运用多 种技术手段和适度开发 策略, 来实现曾经被认

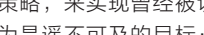
为是遥不保的目标: 山脉周边超过 $405 \mathrm{~km}^{2}$ 的 开放空间。

8. Conservation methods: The plan leveraged multiple techniques and limited dechiques and limited to a hive shat to achieve what had been previously considered impossible - preservation of over 100,000 acres of open space along Colorado's Front Range.
证明，I-25廊道总体保护规划已成功地对一个拥有得天独厚的自然条 件但却面临着巨大的发展压力的区域进行了有效的保护：通过严格的 分析，各种创新的土地保护方法一一包括购买未开发的地块、保护地 役权抵押、采取适度开发策略、为实现集中开发而灵活调整区划— 以及从各个州政府机构获得的支持和资金，曾经一度面临不可挽回的 破坏的弗兰特山脉景观被完好地保留了下来。

这个前所未有的保护项目通过保护秀丽的风景与开放游道和绿 道，也促进了城市增长和休闲活动的发展。该规划还成功地保护了当 地的野生动物栖息地, 以及草原、河滨走廊、孤峰、针叶林和山麓等 生态系统类型。项目在如何通过风景廊道的保护防止都会区陷人无休 止的城市扩张方面树立了典范。LAF
项目信息

项目地址：美国科罗拉多州堡岩城

项目面积: 约 $405 \mathrm{~km}^{2}$

项目委托：美国自然保护基金会

景观规划: Design Workshop设计事务所

首席设计师: Richard Shaw

设计团队: Suzanne Jackson、Sarah Chase、Carly Klein

合作团队/个人：Hunsperger \& Weston地产开发有限公司、科罗拉多州自然保护信托基金会、科罗拉多 州优秀户外项目信托基金会、盖茨基金会、前科罗拉多州州长Roy Romer、道格拉斯郡政府 (包括议事委 员会、开放空间指导委员会、规划部、拉克斯本市政府）、科罗拉多自然资源部、科罗拉多野生动物保护 司、科罗拉多州立公园管理局、科罗拉多公共土地管理局、科罗拉多自然遗产计划小组、科罗拉多交通部 规划设计时间: 1994 2003年 
9. Scenic view protection: Scenic views of the large-scale transition large-scale transition
of prairies to peaks, in including Pikes Peak on adjacent Nation Forest lands, were preserved by analyzing intrinsic landscape values.

\section{Background}

Colorado's Front Range runs parallel to Interstate 25 (I-25) from the Wyoming border to the Colorado Springs. Scenery along this 65 -mile-long corridor is some of the most spectacular in the world, from rolling grasslands to views of Pikes Peak, encompassing historic vistas, working cattle ranches, habitat for a wide array of wildlife, critical ecosystems, and significant recreation activity.

Residents and travelers enjoyed an unimpeded view of this magnificent spine until the last half of the 20th century, when the view and proximity to major metropolitan areas made it a prime target for development. Connecting Colorado's two largest cities, Denver and Colorado Springs, this corridor serves more than 3 million people who live, work, and play in the southern part of Douglas County, which has been one of the fastest-growing counties in the nation since the early 1980s: from 1990 to 1995 alone, its growth rate soared to 45.8 percent, with a great deal of land consumed by road building and subdivisions.

The desire to preserve land and scenic resources in Colorado

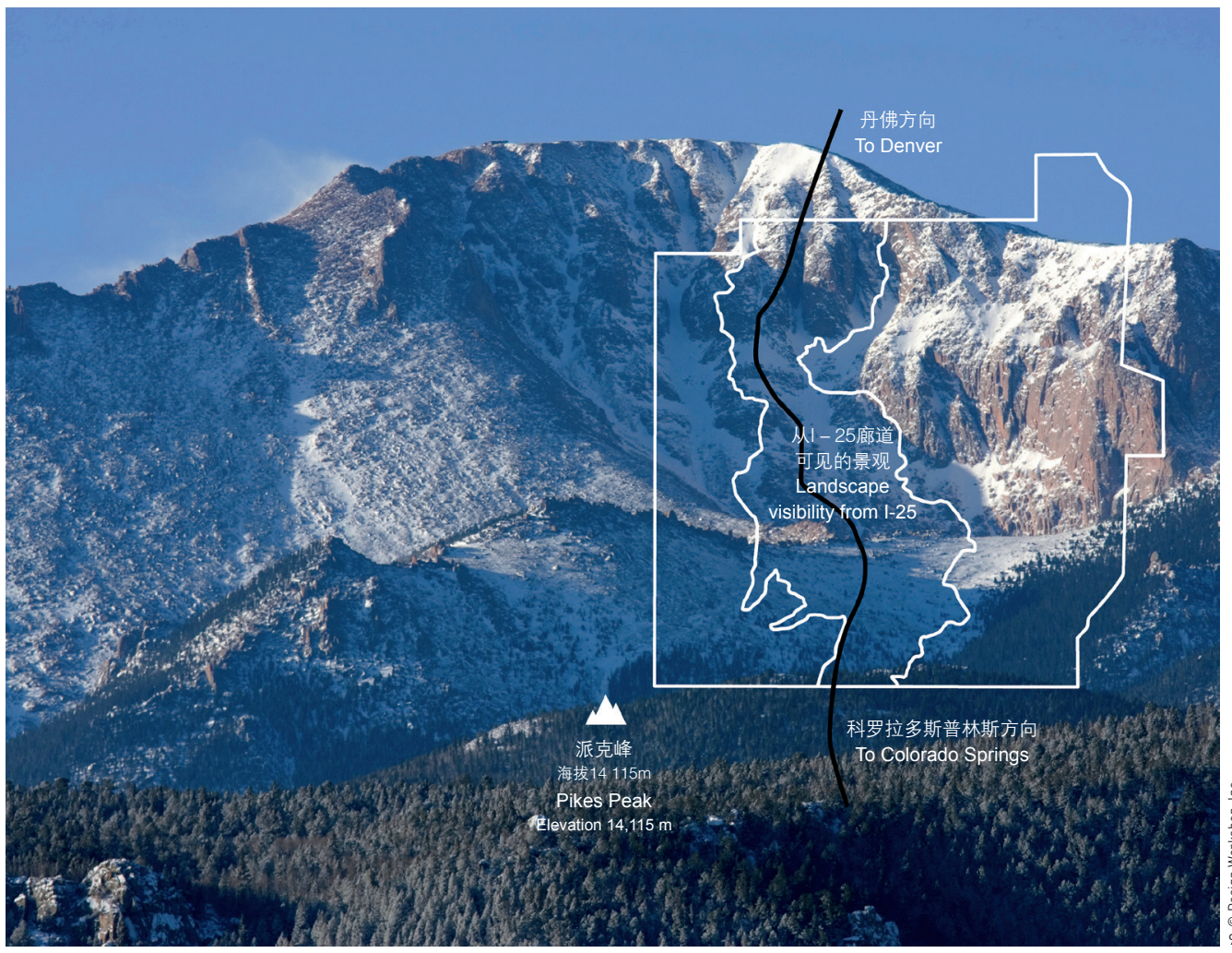

became an increasing priority as construction boosted, while it became continuously difficult to control due to the rapid growth, the high cost of public land acquisition, infrastructure policies that encouraged sprawl, as well as an exception in state law that allowed subdivisions of 35 -acre parcels to be developed without adherence to zoning or other regulations (this exemption ensured that traditional modes of planning can be overturned by any property owner).

Prompted into action by this uncontrolled growth along the I-25 Corridor, Design Workshop, Inc. was selected to lead the development and implementation of an I-25 Conservation Corridor Master Plan to conserve open lands and forever protect scenic vistas, water quality, wildlife, clean air, and recreational opportunities along the corridor, coupled with unprecedented cooperation among conservation organizations, government entities, and private landowners. The plan would leverage multiple techniques and limited development strategies to achieve what had been previously considered impossible: the preservation of broad open space along Colorado's Front Range.

\section{Natural Values}

The natural values of an area of land are a result of the interaction of a range of physical factors, including climate, geology, water, and vegetation. The climate of the Colorado Front Range is semi-arid and is generally a pleasant environment for human activities. However, in the planning area, the climate is strongly influenced by local topography and vegetation around the buttes and ridges, where strong channelization of winds also occurs. The southern end of the planning area forms the divide between the Platte and Arkansas drainages, and is well known for its extreme weather conditions.

Water is undoubtedly one of the most critical issues facing the Front Range as much of the existing development was served by non-renewable groundwater sources, specifically the four aquifers of the Denver basin. Although experts differed in their opinions on how long the existing supply would last, they agreed that future non-renewable supplies would be increasingly difficult to obtain. The planning area was located on the aquifer system and experts believed that the area could contain valuable water resources for the future. Surface water in the planning area includes significant drainages such as Cherry Creek, West Plum Creek, Carpenter Creek, and their tributaries. There are several intermittent streams and numerous stock ponds for cattle. The riparian zones adjacent 
to the watercourses, as well as other bogs and wetlands, are ecologically important areas, and there are sizable floodplains adjacent to the larger drainages.

Three primary ecosystems were identified: grassland, coniferous forest, and brushland. The grassland makes up over half of the planning area and although it was probably once dominated by blue grama (Bouteloua gracilis), introduction of exotic species and overgrazing of decades had altered this ecosystem. Ponderosa pine (Pinus ponderosa) forests are the major conifer association in the area and are located on the drier and sunnier sites. Unfortunately, these forests had been severely impacted through removal for landscape planting and residential development. The brushland primarily occurs between the grassland and coniferous forest and is dominated by scrub oak, which is ideally adapted to the unpredictable climate.

The Colorado Division of Wildlife conducted detailed research in the planning area and noted the increased wildlife activity. In particular, elk herds reside on and migrate through the Greenland Ranch, bighorn sheep can be observed on the rocky cliffs of Larkspur Butte and the sharptail grouse was known to inhabit the area, although the population may be diminishing. In addition, occasional sightings of mountain lion and black bear have been recorded, along with golden eagle, turkey, and herds of deer and antelope.

Together, these natural values created a strong rationale for a preservation strategy. It is significant that the planning area, while providing important ecosystem and habitat centers, is also in an ideal location to link several known ecologically important areas.

\section{Strategies}

The planning area encompassed over 100,000 acres of land and was approximately 15 miles long from north to south. The planning required significant research to pinpoint critical lands, guide implementation efforts, and identify funding sources. Project team collected existing information on natural resource values; identified additional resource inventories which might be needed to identify critical habitats; conducted mapping to identify important visual corridors and scenic resources; contracted for preliminary appraisal work on certain properties; developed recommendations for land protection strategies, including fee acquisitions, conservation easements, leases, and management agreements; analyzed limited development options; initiated landowner contact; investigated and evaluated potential public and private funding sources, including private
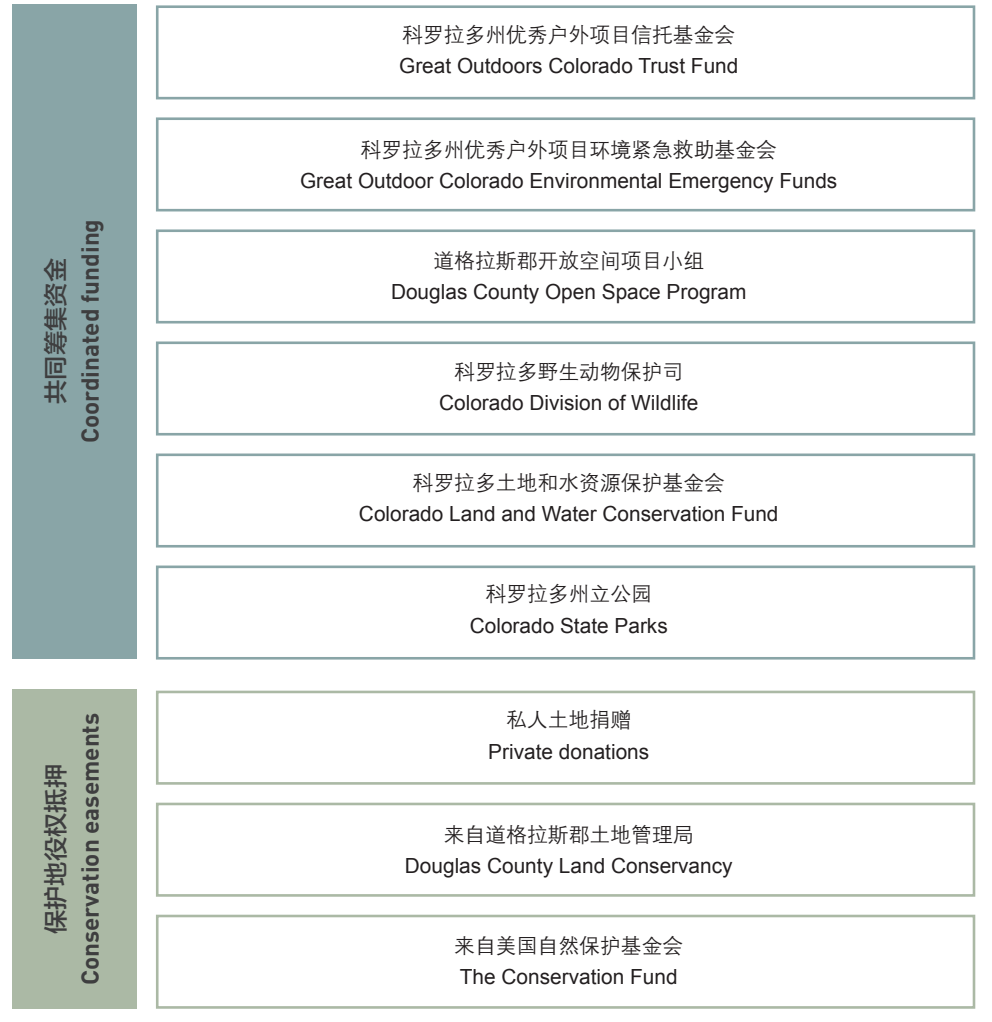

\begin{tabular}{|c|c|}
\hline \multirow{3}{*}{ 蛋莣 } & $\begin{array}{c}\text { 道格拉斯郡分区和土地利用规范 } \\
\text { Douglas County Zoning and Land Use Code }\end{array}$ \\
\hline & $\begin{array}{c}\text { 集群式开发计划 } \\
\text { Clustered Development Incentive }\end{array}$ \\
\hline & $\begin{array}{c}\text { 山地开发条例 } \\
\text { Hillside Development Ordinance }\end{array}$ \\
\hline
\end{tabular}

$\begin{array}{lll}\text { 10. 合作关系: 各个保护组 } & \text { 10. } & \text { Partnerships: } \\ \text { 织, 私人土地所有者, } & \text { Collaboration } \\ \text { 以及州、郡县和地方政 } & \text { between conservation } \\ \text { 府之间通力协作, 在如 } & \text { organizations, private } \\ \text { 何充分利用资金方面达 } & \text { landowners, state, } \\ \text { 成共识, 这对于实现愿 } & \text { and county and local } \\ \text { 景和筹集数百万美元资 } & \text { governments, working } \\ \text { 金以对优先保护地块立 } & \text { together to leverage } \\ \text { 即开展保护工作来说至 } & \text { funding, was essential } \\ \text { 关重要。 } & \text { to realizing the vision } \\ & \text { and securing a multi- } \\ & \text { million-dollar grant } \\ & \text { for the immediate } \\ & \text { acquisition of parcels } \\ & \text { identified as priority } \\ & \text { conservation lands. }\end{array}$



特征, 总体规划对那些 征, 总体规划对那些 已获批但尚未动工的开 发项目进行了“重新安 置”。通过对场地特征 的详细分析, 确保开发 区对于走廊的视觉影响 处在可接受范围内, 同时规划了连续的开放 空间, 并大幅降低居住 密度。

11. Conservationbased development: Approved, yet unbuilt subdivisions were "replatted" to preserve and enhance open space characteristics. Detailed analysis of site features determined a development's acceptable visual impact in the corridor and arranged contiguous open spaces with a great reduction in residential density. investors and conservation buyers.

The team set priorities for lands with complex vegetation, high wildlife count, and important views. Data collection and map production was done over several months, covering scenic view corridors, topography, land cover, natural hazards, land value, zoning, land ownership, view characteristics, wildlife habitat and migrations, ground water availability, recreational trends, heritage sites, and the status of development commitments.

Limited development in the designated parts would help finance acquisition of lands for open space, allow for future growth and economic development, and serve as a model for protecting other lands in Colorado and across the west.

Since the area provides significant recreation and public use opportunities, it was essential that planning ensures Colorado citizens and visitors to experience a wide variety of activities, including traditional recreation such as hiking and biking, as well as activities involving watchable wildlife and environmental education.

Based on the area's natural values, three categories for preservation were identified. The most critical preservation area or the high wildlife sensitivity area comprises approximately 4,500 acres. These areas should be maintained in their existing condition or managed for their natural or wildlife habitat, with minimal human use. The rest areas allow limited human activity.

\section{Stakeholders, Priorities, and Conflicts}

A key goal of the project was to involve a wide range of public and private partners in the planning process. A series of meetings and workshops were held to develop awareness and gather information from interested and affected parties. Stakeholders included:

1) State governments: Colorado Office of the Governor and Colorado Department of Transportation;

2) County governments: Douglas County Board of County Commissioners, Douglas County Open Space Advisory Committee, and Douglas County Planning Department;

3) Municipal government: Town of Larkspur;

4) Corporations: Mission Viejo Company (developer) and Hunsperger \& Weston, Ltd. (real estate appraisal);

5) Quasi-governmental organizations and nonprofits: Great Outdoors Colorado Trust Fund, Colorado Conservation Trust Fund, Gates Foundation (now the Gates Family Foundation), Colorado Open Lands, and Colorado Natural Heritage Program;

6) Residents and landowners.

The feedback was overwhelming. Residents placed a high priority on preserving open space, particularly for lands where critical wildlife habitat and stream corridors were present. The participants agreed that the plan could serve as an economic

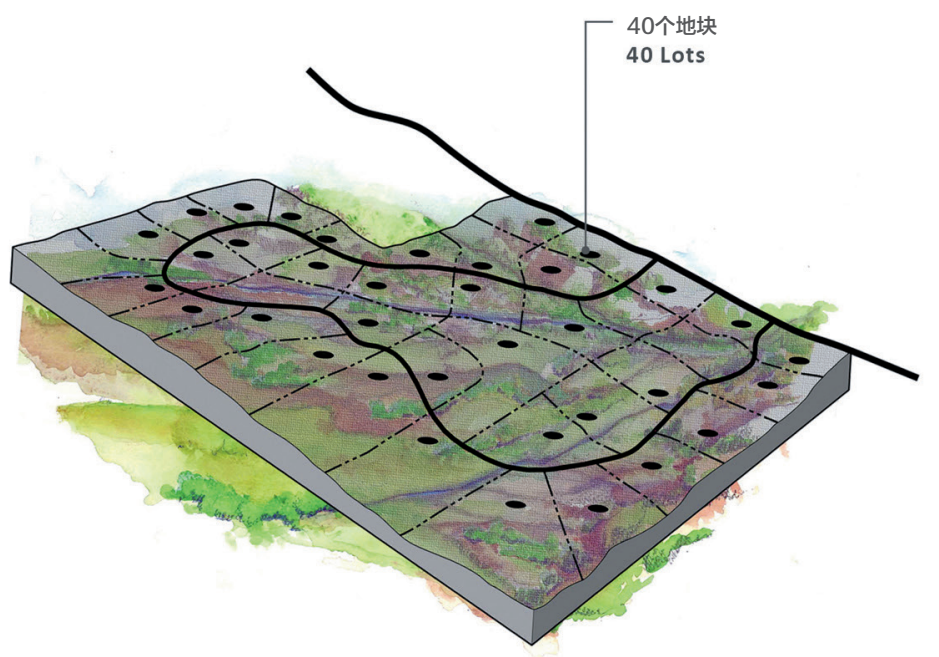

原始地块划分 Original subdivision approval

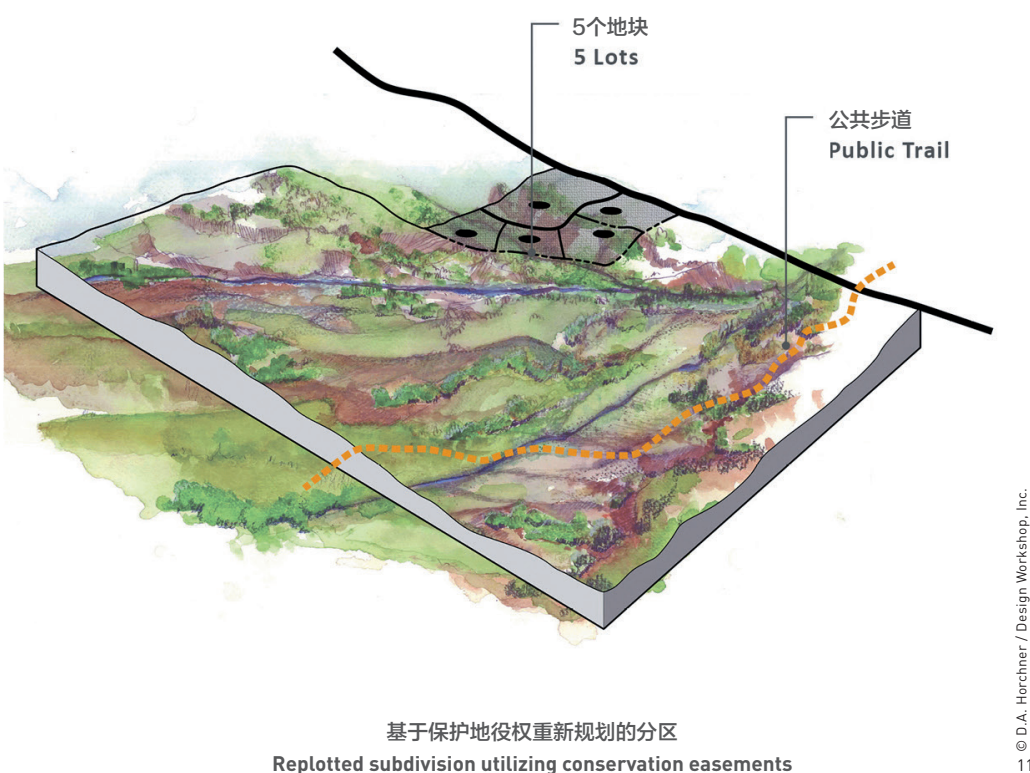




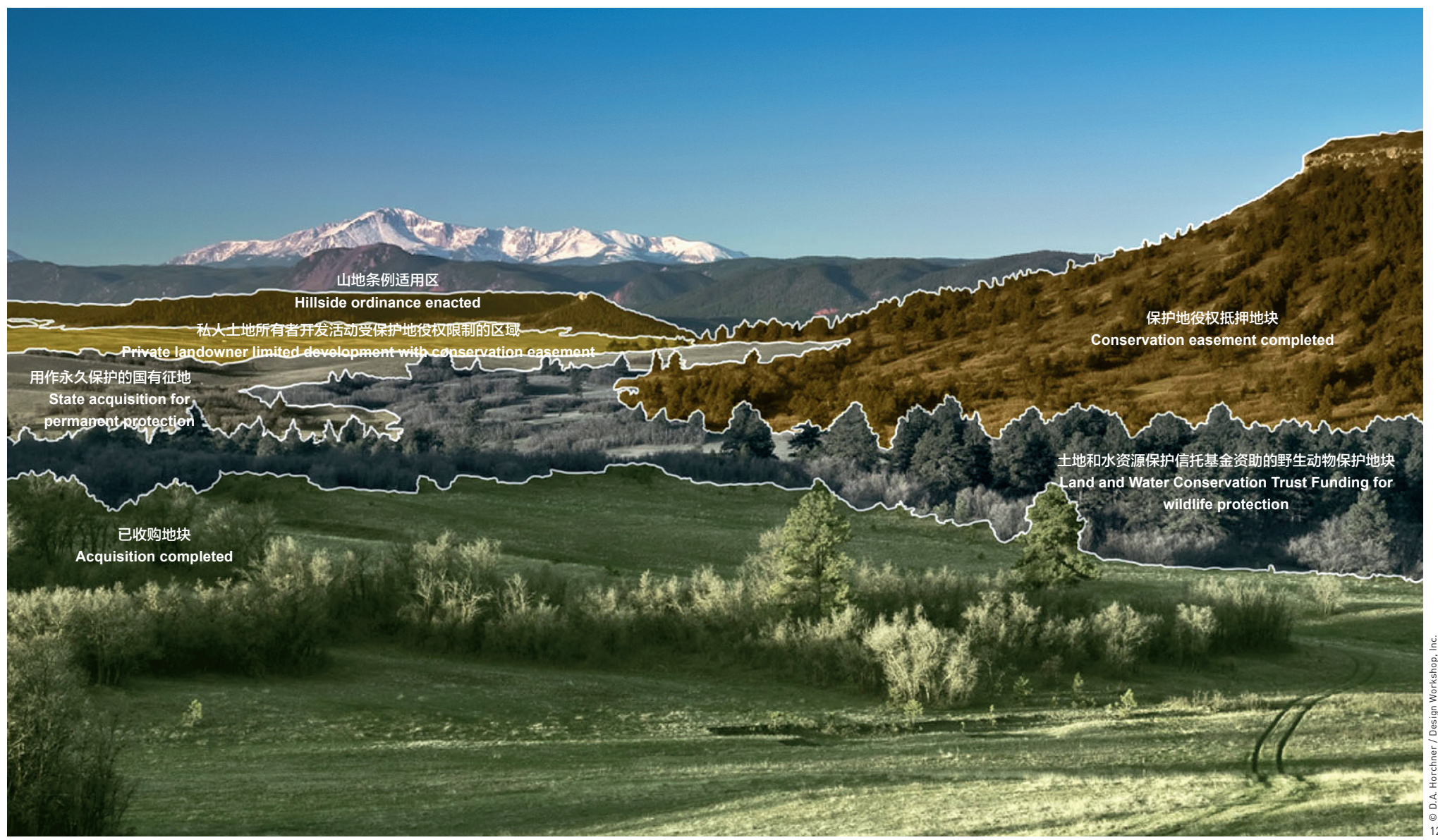

12. 随着规划团队从 “愿景 规划” 过渡到实施阶 段, 更加复杂的土地交 段, 更加复条的土地交 易问题开始浮现。该总 体规划创造性地将严谨 的分析和规划方法运月 到多个方面的协作过程 中, 以保护科罗拉多州 宝贵的开放空间体系。

12. The complexities nherent in land transactions increased as the planning team transitioned from "vision planning" to implementation. The master plan creatively combined rigorous analysis and planning methodologies with a multi-faceted collaboration approach to protect Colorado's legacy of open space.

enhancement for Douglas County, and a sense of urgency was expressed by all stakeholders.

The urban growth analysis models were utilized to forecast locations along the corridor that were likely to be developed first. Land ownership boundaries in the planning area were distinctive, with several large land holdings under single ownerships. The properties ranged in size from approximately 900 acres to 21,000 acres. Development approaches that would be most desirable included:

1) Development that was clustered in less sensitive areas so that valuable open space parcels can be preserved. For example, in an area zoned for one residence per 35 acres, three residences might be developed on 15 acres of land, while the remaining 90 acres was preserved. Douglas County encouraged this type of development.

2) Under a limited development, fewer buildings than permitted by existing zoning were created, with a conservation easement encumbering the remainder of the property.

3) Minimum subdivision lot size of 160 acres, rather than 35-acre minimums. This option was presently under consideration by Douglas County, but required state legislation.

The team used historic patterns to create a predictive model that matched these locations against the sites with the most natural and scenic resources to reveal potential conflicts and establish preservation priorities. Finally, by locating limited development in places where it minimized the impact on the land and did not harm habitat or encroach on views, it was possible to preserve land around development, which in turn would increase the value of the land.

\section{Recommendations and Implementation}

Despite being armed with a vision, public support, and a roadmap for future preservation, the plan's success was initially curtailed due to the lack of county regulations directing location, type, and pace of development. The team refocused implementation of the planning efforts through collaboration with conservation organizations, private landowners, 
state, county, and local governments to secure funding for the immediate acquisition of parcels identified as priority conservation lands.

The turning point came when the Conservation Trust Fund secured a multi-million-dollar Legacy Initiative grant in 1996 to begin the immediate acquisition of parcels identified as priority conservation lands. Additional fundraising facilitated the purchase of areas zoned for dense development. The team also proposed that all future development plans for land in the corridor purposely cluster and site houses out of public view, place any remaining land in permanent conservation easements, and confer tax benefits on the future owners, ultimately preserving both open space and views in perpetuity.

Recommendations for the potential development sites were based on factors such as aspect, views, vegetation, proximity to roads, engineering feasibility, and orientation. Certain areas were eliminated based on constraints such as flood plains, steep slopes, and geologic hazards. In addition, lands which were already subdivided or developed (less than 2.5 acres) were excluded from further development potential.

Funding was allocated to areas where it would be most effective, forming the basis for informed decision making, consensus building, and negotiation. Importantly, while the plan succeeded in encouraging developers to consider the value of scenic and natural resources in subdivision planning, it was also instrumental in convincing conservationists that appropriate development can support land preservation.

The complexities inherent in land transactions increased as the planning team transitioned from "vision planning" to implementation, and the designers played a key role in many of them. In one dramatic move to complete the vision, the Conservation Trust Fund underwent an 11-hour intervention to secure a key 1,300-acre property on which road building and grading had already begun for 40 houses. The land offered the best public view of Pikes Peak along the corridor. Using napkin sketches created by the landscape architect that illustrated sensitively clustered residential lots, the developer was convinced to replot the property, effectively removing all residential lots from public view.

Over the following decades, development itself became an important method for preserving lands. The effectiveness of the I-25 Conservation Corridor Master Plan can be measured through its efforts to preserve an area enjoying a prominent natural values but facing such acute development pressures. Through rigorous analyses, a variety of innovative land conservation methods - including the purchase of undeveloped lots, conservation easements, limited development strategies, and zoning changes to clustered development - and the support and funding received from various state agencies, a quintessential Front Range landscape on the verge of irreparable change was preserved.

This unprecedented conservation project helped shape urban growth and recreational development by preserving scenic views and open space trails and greenways. The plan protected wildlife habitats, as well as ecosystem types such as prairie, riparian corridors, buttes, pine forests, and foothills. The project stands as a model for how to keep metro areas from merging into continuous urban sprawl by guaranteeing preservation of a scenic corridor. LAF

\section{PROJECT INFORMATION}

Location: Castle Rock, Colorado, USA

Area (size): 100,000 acres

Client: The Conservation Fund

Landscape Planning: Design Workshop, Inc.

Chief Designer: Richard Shaw

Project Team: Suzanne Jackson, Sarah Chase, Carly Klein

Collaborators: Hunsperger \& Weston, Ltd., Colorado Conservation Trust Fund, Great Outdoors Colorado Trust Fund, Gates Foundation, Former Colorado Governor Roy Romer, Douglas County (Board of County Commissioners, Open Space Advisory Committee, Planning Department, and Town of Larkspur), Colorado Department of Natural Resources, Colorado Division of Wild life, Colorado State Parks, Colorado Open Lands, Gates Corporation, Colorado Natural Heritage Program, Colorado Department of Transportation Planning and Design: 1994 2003
13. 项目将其所描绘的宏大 愿景一一实施, 如今实 现了对这条国家级重要 现了对这条国家级重要 廊道中的开放空间、公 共休闲空间、观景视野 和野生动物栖息地进行 永久保护。

13. Starting with a powerful vision, this plan is now a reality that has of a nationally important corridor with permanently protected open space, public recreation, scenic views, and wildlife habitat.

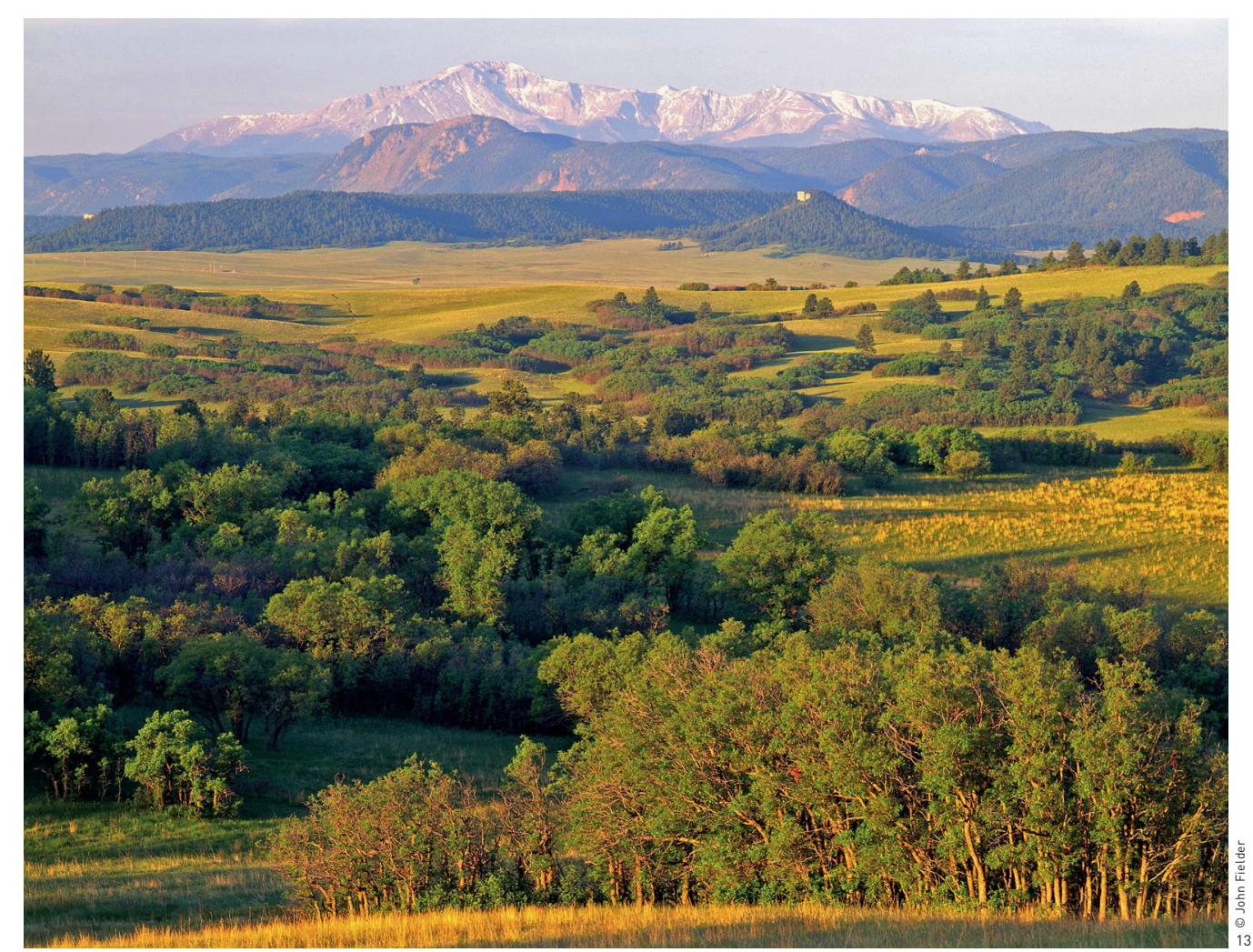

